\title{
FROM LANGUAGE TO EMPIRE: WALT WHITMAN IN THE CONTEXT OF NINETEENTH-CENTURY POPULAR ANGLO-SAXONISM
}

\author{
Heidi KathleEn Kim
}

\begin{abstract}
Anglo-Saxonism in NineteEnTH-CENTURy America took many forms, ranging from an academic interest in the Anglo-Saxon language to fullout declarations of the supremacy of the modern Anglo-Saxon race. Few people, however, had quite as complex a relation to the Anglo-Saxon movement as Walt Whitman, whose poetry and other writings manifest contradictory views towards America's claim of pure Anglo-Saxonness. Critical description of Anglo-Saxonism frequently omits serious discussion of Whitman, fueled no doubt at least in part by his reputation as the democratic poet who sought to unify the cosmos. However, as a journalist and literary figure, it would have been nearly impossible for Whitman not to hear and respond to the intense contemporary interest in Anglo-Saxon. While Whitman's goal appears to be to erase racial difference through his project of a unified America, his vocabulary of Anglo-Saxonism problematizes the call for equality and universality. His acclamation of American language and the American race complicates his explicit valorization of English hereditary traits, while his poems celebrating universality cannot entirely erase the impression of AngloSaxon imperial domination. Only when he specifically contradicts aspects of common imperialist-Anglo-Saxonist claims does he succeed in silencing the ghosts of his own rhetoric. As Eric Lott writes, "Whitman is a salutary reminder that there is no simple correspondence between individual racial feeling, cultural predisposition, and political ideology." Nor, as Jay Grossman adds, is there necessarily any consistency in this correspondence over time. ${ }^{2}$ Examining Whitman's writings to form a single conclusion about his Anglo-Saxonism is futile, but his changing focus from language to racial superiority and then to the postbellum negation of that superiority demonstrates the complexity of Whitman's politics.
\end{abstract}

Whitman's racial and national politics have been the subject of innumerable critical works, which have examined him from many angles. Anglo-Saxonism cannot be separated from other movements of the time; 
regarding Ralph Waldo Emerson's English Traits (which he considers more about racial "Americans" than the English), Dana Phillips argues that Emerson was "renewed by his British experience in something other than the Transcendentalist way." 3 Anglo-Saxonism, Transcendentalism, and other philosophies must be read as part of a complex conversation. For example, in Ali Behdad's recent criticism of Whitman, he reads Leaves of Grass as a monumentalizing work that flattens out productive (racial) tensions in search of a trans-historical point of view that verges on the ahistorical. How then might Behdad, whose study centers on immigration and racial erasure, read the Anglo-Saxonist threads of Whitman's rhetoric that connect America and Leaves to a far distant history still alive and working in the present? His work contrasts with that of Phillips, who finds that the racial catalogs of Leaves reveal a deep ambivalence about America's need for racial vitality. For Phillips, the body is the point of intersection; for Behdad, it is the ahistorically presented geography. But these studies are most effective when contextualized with the various ramifications of a single idea. Anglo-Saxonism, like other philosophies, was not just about the body or about territory; it was a world view encompassing everything from language to empire.

The use of Anglo-Saxon formed a sort of sliding scale, along which people might stop at any point. The most fundamental element was the interest in the language, which flared up in the 1840s. Schoolbooks began teaching Anglo-Saxon derivatives as the foundation of English, and several grammars and commentaries were published. Interest in the language itself ranged from the mildly pedagogical to the extreme, such as the periodical The Anglo-Saxon which established an entirely new alphabet and spelling for a revived Anglo-Saxon language. Nor was this a fanatical singularity; the periodical reached a weekly circulation of 6,000 within its first year, no small achievement. ${ }^{4}$ Oratorical style, which C. Carroll Hollis cites as a chief influence on Whitman's poetics, ${ }^{5}$ was also debated in terms of floweriness versus a straightforward Anglo-Saxon style, such as that exemplified by Henry Ward Beecher. ${ }^{6}$

Language was interwoven with the characteristics of race, according to linguistic and racial theories of the time. Unsurprisingly, popular interest focused on the superiority of the Anglo-Saxon-derived English language and the Anglo-Saxon-descended English and American races. The rise of Anglo-Saxonism in the nineteenth century was not a new development, but whiteness scholars such as Matthew Frye Jacobson have argued that the rapidly changing demographics of the "white" American population (particularly the influx of Irish) led to a xenophobic emphasis on a hierarchy of whiteness, with the Anglo-Saxons at the top. ${ }^{7}$ This racialism was used in debates about nationalism, expansion, both assimilatory and exclusionary immigration, and, of course, slavery, in which the Anglo-Saxons were posited as the ultimate contrast to the 
Africans.

Anglo-Saxon superiority was supposedly apparent in their domination of the world in commerce and politics. The influence of AngloSaxon practices, ranging from religion to commerce and including the modern English language, was celebrated and used as yet another reason to study the language of the Anglo-Saxons more carefully. A religious periodical asserted:

In the actual and prospective spread of the English tongue, we find a new motive to study it fundamentally. The language of the venerable Bede is spoken at the sources of the Mississippi and the Indus. ... Anglo-American energy is peopling a continent with those who revere and love the great names that live in British story. English armies and navies are carrying the Ante-Norman dialect into the vale of Cashmire, over the wall of China, into the cannibal islands of the southern ocean. ... Happy are we who enjoy the language, the liberties and the religion for which so many generations have toiled and bled. ${ }^{8}$

Of course, the more the language gained in superiority, the more reason there was to carry the language and its accompanying liberties to new regions. Popular thought thus set up a vicious circle of expansion and supremacy. To many, Anglo-Saxon superiority justified further expansion as well as past expansion. To some of these, it justified both peaceful and military expansionism; others justified expansionism evangelically. Some felt that superiority justified a ban on immigration. ${ }^{9}$

Talk of expansion and imperialism focused on diverse forms: direct political domination, commercial domination, or religious conversion. Contemporary articles exulted in the domination of the Anglo-Saxon race, which controlled the "business and politics" of "both hemispheres." 10 Religion was another source of unity and a reason for expansion; there was already a historical tradition positing the Anglo-Saxons as a preReformation model of the church in England, an almost proto-Protestant individualistic Church. ${ }^{11}$ The National Era postulated a noblesse oblige for the Anglo-Saxons to spread Christianity, improving upon the Spanish and Portuguese who had enslaved but failed to convert the New World. ${ }^{12}$ This mixture of altruism and pragmatism provided fodder for decades of justification for expansion and imperialism.

How expansion was to be carried out was a subject of further debate among Anglo-Saxonists. Reginald Horsman, in Race and Manifest Destiny, cites Theodore Parker as a popular public speaker who was an Anglo-Saxonist in favor of peaceful expansion, and who therefore opposed the Mexican War. But one of Parker's reprinted sermons offers contradictory feelings about the race's proclivity towards war, as Parker claims that Anglo-Saxons are superior in "plain and practical sense, in industrial activity and political sagacity. .. This race is industrial and commercial more than military." A few sentences later, he reverses himself 
and declares, "There is no race in the world to equal it in war, thought, industry, or politics, because it is by nature fitted for that work." ${ }^{13}$ The unequaled Anglo-Saxon talent for war found its outlet in westward expansion (and later nineteenth-century global expansion) despite publicly debated qualms. Whether such qualms were ethical, rather than due to the fact that northeasterners were less likely to derive direct benefits from territorial accession, is naturally difficult to determine. ${ }^{14}$ Certainly, the National Era viewed the Mexican War's encroachment upon liberty as a mistake for which Anglo-Saxon America might later reap the punishment. ${ }^{15}$

All of these intersecting views produced an extremely complex landscape, in which people debated everything from rhetoric to providential manifest destiny in the context of Anglo-Saxonism. Combined with the considerable rhetorical gymnastics that were necessary to address the question of just how Anglo-Saxon a racially diverse America really was, nineteenth-century popular thought on the subject was far from monolithic. These popular views, while not necessarily Whitman's own, can be used to understand how his mentions of Englishness and Anglo-Saxonism complicate his efforts to communicate a politics of unity and equality.

Discussion of Whitman's Anglo-Saxonism rests initially on language; interestingly, Anglo-Saxon literature fails to appear in most popular discussion, including Whitman's. Literature was certainly part of more scholarly interest, as excerpts were featured (in translation with snippets of the original) in Henry Wadsworth Longfellow's Poets and Poetry of Europe (1845) and Sharon Turner's reissued three-volume History of the Anglo-Saxons (1805/1852). Critical dismissal of the Anglo-Saxon literature shows that literary theory evidently had not followed linguistic theory; the same rudeness and simplicity that people valued in Anglo-Saxon were deemed unsatisfactory in the literature. ${ }^{16}$ Whitman himself, while valuing "primitive" or "aboriginal" poetry, refers to Irish or Native American poetry and omits mention of Anglo-Saxon; ${ }^{17}$ his discussion of Burns, for example, refers to Homer and the classics, but not Anglo-Saxon poetry. ${ }^{18}$ The extent of his familiarity with it is difficult to determine, but it was certainly available and well-known through the aforementioned volumes, among others. His interest in history is documented in a series of notes taken around 1855 from the Pictorial History of England, ${ }^{19}$ most likely the multi-volume work by George L. Craik and Charles MacFarlane. ${ }^{20}$ (An American Review critic noted that Craik was much more readable but far less erudite on the subject of the Anglo-Saxons than Turner; ${ }^{21}$ Craik's book was also extremely cheap.) Whitman's notes focus on the Anglo-Saxon period of England, but offer little elucidation of his Anglo-Saxonist politics. 
On language, however, his views can easily be found in two main sources: a posthumously published essay, or rather a compendium of notes originally written in the 1850 s and 1860 s, edited by Horace Traubel and entitled "An American Primer," and an 1856 Life article by Whitman entitled "America's Mightiest Inheritance." These, along with the introduction to the 1855 edition of Leaves of Grass, provide a fairly comprehensive portrait of Whitman's language views in the $1850 \mathrm{~s} .{ }^{22}$ Whitman shared many of the prevailing views about the English language's reliance on the fundamental qualities inherent in Anglo-Saxon. John Bernbrock discusses the extreme similarity between Whitman's language writings and the series of texts published by the Literary Association, chiefly $A$ Hand-Book of Anglo-Saxon Derivatives and A Hand-Book of Anglo-Saxon Root-Words. ${ }^{23}$ Whitman's restatement of the Association's characterization of the "Anglo-Saxon stock of our language" pronounced it to be "the most important part, the root and strong speech of the native English for many centuries, [which] mainly serves for sensible objects, specific thoughts and actions, home, and domestic life; it has the best words for manliness, friendship, and the education of childhood." ${ }^{24}$ This reflected the common feeling about Anglo-Saxon as foundational, therefore providing the most basic vocabulary, while English had borrowed specialized words from Latin, French, and other languages. The emphasis on emotional expression - manliness, friendship - was important to Whitman, as well. He underscored key sections of an article in the Edinburgh Review:

The Saxon element, on the other hand, is the one in which moral truth resides. Its brief appeals come home to us immediately, not mediately; address our whole being and not a portion of it, and thus, borne in upon us instantaneously and intensely, speak directly to the heart, in its own words of pathos and of power. Neither part of our language should be deprecated; but wherever the Saxon part conveys the exact meaning, it conveys it best; and by those writers whose merits are truth and strength, it will ever be made the substance of their diction. ${ }^{25}$ [Whitman's underscoring]

In the margins, Whitman noted, "I think the Saxon has an element no other language has." He also opined that Anglo-Saxon had words of "more friendship and love" than any other race, but "less of the words of the various phases of friendship and love." ${ }^{26}$ Hence, the unique Saxon "element" is presumably its "truth and strength," as well as its emotional directness, which provide words expressing emotion directly rather than through mediate, lengthy description.

These qualities in the language were inseparable from the supposed qualities of the race. Whitman wrote, "The English tongue is full of strong words native or adopted to express the blood-born passion of the race for rudeness and resistance, as against polish and all acts to give in: Robust, brawny, athletic, muscular, acrid ..." (AP 463). Both strength and a 
tradition of political freedom had long been ascribed to the English and then extrapolated back to the fighting Anglo-Saxons. As Whitman further theorized, "Character makes words. The English stock, full enough of faults, but averse to all folderol, equable, instinctively just, latent with pride and melancholy, ready with brawned arms, with free speech, with the knife-blade for tyrants and the reached hand for slaves-have put all these in words. We have them in America,- - they are the body of the whole of the past. We are to justify our inheritance,-we are to pass it on to those who are to come after us, a thousand years hence, as we have grown out of the English of a thousand years ago" (AP 462). This conception of America's destiny was widespread, but the definition and extent of "those who are to come after us" would prove to be a point of much contention.

But Whitman's own language experiment clearly did not rely solely on Anglo-Saxon. His use of Anglo-Saxon poetics has been discussed, ${ }^{27}$ and whether his rhythms follow the "natural" rhythms of Anglo-Saxon poetry deliberately is difficult to determine; besides which, his poetics have been attributed variously to other influences, from French to Native American ${ }^{28}$ His compound words, "coinages like 'tap-root' ... strewn as they are throughout Whitman's prose - testify to a fascination with the transitive, engendering force in language itself," notes Kerry Larson. ${ }^{29}$ This fascination is quite probably influenced by the Anglo-Saxon tradition of kennings, prominently mentioned in Longfellow's essay in Poets and Poetry of Europe (the example he gives is laughter-smith). Words such as "greenshine," "ever-pushed," or "shipcarpent-ering" are Whitman's vivid modern-day kennings. Such constructions, however, could as well be ascribed to the larger Germanic linguistic influence. ${ }^{30}$

It appears that Whitman was uninterested in the more extreme forms of Anglo-Saxon linguistics, such as contemporary revivals of Anglo-Saxon. Instead, the key to Whitman's attitude towards AngloSaxon can be found in the word "stock." In the 1855 introduction to Leaves of Grass, he wrote:

The English language befriends the grand American expression. ... it is brawny enough and limber and full enough. On the tough stock of a race who through all change of circumstance was never without the idea of political liberty, which is the animus of all liberty, it has attracted the terms of daintier and gayer and subtler and more elegant tongues. It is the powerful language of resistance . . . it is the dialect of common sense. It is the speech of the proud and melancholy races and of all who aspire. It is the chosen tongue to express growth faith self-esteem freedom justice equality friendliness amplitude prudence decision and courage. It is the medium that shall well nigh express the inexpressible. ${ }^{31}$

Despite the fact that the Anglo-Saxon stock was the "most important," Whitman celebrated the diversity of additions. He particularly admired 
Native American geographical names (Mannahatta, for instance), and the reference in "Prayer of Columbus" to "anthems in new tongues" may well refer to the indigenous languages of the New World ( $L G 423$ ). Whitman's essays also praised the constantly evolving slang of different localities and occupations. Referring to foreign additions, he described English as a "treasure house, or ranges of treasure houses, arsenals, granary, chock full of so many contributions from the north and from the south, from Scandinavia, from Greece and Rome-from Spaniards, Italians, and the French.” He also noted, “[English's] own sturdy homedated Angles-bred words have long been outnumbered by the foreigners whom they lead-which is all good enough, and indeed must be" ( $A P$ 468). This qualified statement, particularly the resignation inherent in "enough" and "must be," reads oddly next to the positive sense of "treasure house," but Whitman's other enthusiastic appreciations of loan words seem to indicate that his sympathies truly lay with the evolution of the language.

F. O. Matthiessen lays great stress on language as Whitman's unifier, ${ }^{32}$ but Whitman's discussion of Anglo-Saxon racial traits, added to his language project, complicates the project of unity. Though Whitman's delight in new words tempers his linguistic Anglo-Saxonism, the rhetoric of contemporary Anglo-Saxonism swamps the modifying images in his poetry. Like so many others who were interested in Anglo-Saxon linguistics, his racialized Anglo-Saxonism inevitably brings about discussion of both race and racial domination, leading to imperialism.

At the same time that Whitman was struggling to juggle the importance of Anglo-Saxonism and the diversity of American English, he was also exploring its implications of racialism and racial domination. Whitman ascribed some of his own characteristics to racial heredity, again referring to "stock": "the maternal nativity-stock brought hither from far-away Netherlands, for one, (doubtless the best)- the subterranean tenacity and central bony structure (obstinacy, wilfulness) which I get from my paternal English elements, for another." ${ }^{33}$ Here, in 1860, the Dutch are the "best"-perhaps related to his affectionate relationship with his mother-and the English obstinacy and willfulness come second. In "Song of Myself," however, a sea captain has "English pluck, and there is no tougher or truer, and never was, and never will be" ( $L G$ 69). Similarly, English traits are praised in a fragmentary note about the San Francisco Vigilance Committee of 1851 or 1856: "In California, the people, ever instinctively sturdy, ever instinctively just, by right of Teutonic descent, are just beginning to awake to these things-have but to perceive any great wrong, and the work of redemption is begun from that hour.-I heartily approve of the California Vigilance Committee; it is worthy of the sternness and courage of the Anglo-Saxon race." ${ }^{34} \mathrm{On}$ a literary level, Whitman attributed Carlyle's strength as a writer to his 
Gothic stock, not Latin or Greek ( $P W$ 248). Pluck, justice, sternness, and courage are all racialized towards a pure Anglo-Saxon supremacy.

Whitman's own pro-expansionist views can best be derived from his early editorials and poetry. The tendency of the race towards war was expressed around 1855: "I will at once admit there is something in us as a race, as races, that, against peace, against solidity, against enjoyment, restless, hungry, offensive, full of danger, full of death, often unable to account for itself, will allow nothing to remain established." 35 This tendency against peace, and towards destruction, sets America as a "race" (which readers would be quite likely to read as an Anglo-Saxon race, or at least an Anglo-Saxon-based race) or "as races" against other races; his language theories, following the typical practice of seeing English traditions of liberty reflected in the language, describe subservience in other races and languages: "The races that in their realities are supple, obedient, cringing, have hundreds of words to express hundreds of forms of acts, thoughts, flanges, of those realities, which the English language knows nothing of" ( $A P 463)$. Such views were probably written out after the Mexican War, a war which Whitman approved for ostensibly altruistic reasons, writing in an editorial, "We pant to see our country and its rule far-reaching, only inasmuch as it will take off the shackles that prevent men the even chance of being happy and good." Assertion of the superiority of English and American rule, despite the aforementioned major faults of each, was a commonplace in justification of expansion. Very early editorials ofWhitman's in 1846-1847 had asked, "What has miserable, inefficient Mexico ... to do with the great mission of peopling the New World with a noble race?" News of a military victory was hailed as "another clinching proof of the indomitable energy of the Anglo-Saxon character," explicitly linking these views to Anglo-Saxonism. ${ }^{36}$

While Whitman acclaimed the Anglo-Saxons for strength and courage, others looked at the expansion unrolling before their eyes and drew further conclusions about that strength. A careful discussion of American colonization in the American Whig Review concluded, "We thus see that the British North American colonies were settled almost exclusively by Anglo-Saxons, and their rapid progress was owing in a great degree to the energy and vigor peculiar to the race to which they belonged." ${ }^{37}$ Such views can be used as a lens through which to interpret the blond patriarchal fisherman of "I Sing the Body Electric," an image which would appeal instantly to popular conceptions of the AngloSaxons idealized and utilized in literature throughout the nineteenth century. ${ }^{38}$ Drawing upon contemporary unease about the dwindling physical powers of white Americans, ${ }^{39}$ Whitman provides a figure who has already listened to Whitman's injunction to cast aside books and to go outdoors. While some might argue that the figure of the robust negro at auction is an equalizing force for the image of the robust fisherman, 
the negroes are alone and probably being torn from their families - while the fisherman sits enthroned among his hearty progeny. The promise of "nations" within the negro has already been fulfilled for the AngloSaxon representative.

During and after the Civil War, it would be surprising if these views did not change. The exclusion of "Great Are the Myths" from Leaves of Grass after 1867 provides a dynamic case study for Whitman's changing Anglo-Saxonism. In this, the last poem of the 1855 edition, Whitman extols the cosmic and the particular - from life and death to reformers and the international mail. Here, altruistic imperialism appears explicitly:

Great is the English speech .... What speech is so great as the English?

Great is the English brood .... What brood has so vast a destiny as the English?

It is the mother of the brood that must rule the earth with the new rule,

The new rule shall rule as the soul rules, and as the love and justice and equality that are in the soul rule. ${ }^{40}$

The greatness of the English speech, whether through its Anglo-Saxon stock or the engrafting of foreign languages, leads directly into the greatness of the race and its rule. The English produce the brood - presumably the Americans, if not the modern English-who will improve the world with their benevolent rule. This sounds like the Whitman of 1846, who wanted to give other men the chance to be "happy and good." But altruistic imperialism is still imperialism.

As far as I can tell, there exists no documentation of Whitman's reasons for cutting the poem after 1867. Nevertheless, the revisions of 1867 indicate a serious shift in Whitman's thought. The antebellum optimism about "this age," the "throes and triumphs and falls of democracy," the reformers, and even "yourself and myself" has been deleted (LGVar 155). Most pessimistically, perhaps, the verse, "Great is the greatest nation ... the nation of clusters of equal nations" has been omitted (LGVar 156). Glory in America as the greatest nation, along with its "marriage, commerce, newspapers, books, freetrade, railroads, steamers, international mails and telegraphs and exchanges," is no longer possible postbellum (LGVar 158); however, in 1867, the "English brood" verse remains to establish potential for a resolutely unified future.

The excision of the poem after 1867 makes one wonder whether Whitman found the tone of the poem to be altogether too optimistic, even for a generally exuberant work like Leaves of Grass; had he wanted to excise the Anglo-American politics, the poem might have read like a paean to abstract ideals. Betsy Erkkila calls the conclusion an "affirmation that is declared rather than earned," ${ }^{11}$ and as the specific affirmations are proved faulty, the greatness crumbles. She also finds that the poem fails because the "potentially divisive forces in self, nation and cosmos offer the least resistance to Whitman's unifying act" (my italics, 118). 
But the Anglo-Saxonism of the "English brood" verse offers a stupefying resistance to the unity of a diverse population. While not necessarily cause and effect, in the wake of the Civil War, this racial resistance to unity is deleted and, as Erkkila notes, never earned.

In contrast, the more complex politics of "By Blue Ontario's Shore" gain in complexity from one version to the next. In its original 1856 version, "Poem of Many In One," an entire verse is devoted to the English language, echoing the 1855 Preface and describing English in typically hyperbolic Anglo-Saxonist terms:

\author{
Language-using controls the rest; \\ Wonderful is language! \\ Wondrous the English language, language of live men, \\ Language of ensemble, powerful language of resistance, \\ Language of a proud and melancholy stock, and of all who aspire, \\ Language of growth, faith, self-esteem, rudeness, justice, friendliness, amplitude, \\ prudence, decision, exactitude, courage, \\ Language to well-nigh express the inexpressible, \\ Language for the modern, language for America. (LGVar 200)
}

"Ensemble" refers to the multiple linguistic origins, but the single "stock" that expresses rudeness, justice, friendliness sounds like previous descriptions of the Anglo-Saxon roots. Like most of Whitman's other explicitly theoretical linguistic work, however, this passage comes from the mid-1850s. By 1860, the linguistic claim has been excised as the poem shifts to a more philosophical tone; perhaps Whitman's language enthusiasm (as well as popular enthusiasm) had dwindled slightly, or else his Anglocentric enthusiasm seemed unsuitable for the direction that the poem was taking. In 1867, Whitman added a preface in which the writer sits by blue Ontario's shore and a Phantom comes to exhort him to chant a poem of America. Interestingly, just as the greatness of the "throes and triumphs and falls of democracy" is deleted from "Great Are the Myths," Whitman is told to chant a "song of the throes of Democracy" (LGVar 190). It is no longer assumed to be great, and the topic that was previously celebrated in passing or taken for granted becomes the topic of a lengthy poem.

American supremacy has not disappeared from "Ontario." Americans are a "breed whose testimony is behaviour" in 1856, but then Whitman changes to a more futuristic epithet: "a breed whose proof is in time and deeds"-perhaps again because of the focus on the throes of democracy, not its triumphs. America is celebrated in immense geographical and social detail, once again emphasizing America's superiority, for "any period one nation must lead, / One land must be the promise and reliance of the future" (LGVar 191). One breed carrying the future sounds rather like the English brood that was supposed to rule with the 
new rule, creating a possibly Anglo-Saxonist paean.

But after 1860, Whitman has also added both new vocabulary and new ideas which actively contradict the familiar strains of Anglo-Saxonism. The notion of "Libertad," rather than Liberty, enters Whitman's vocabulary over time; to give the crudest empirical idea of this change, "Libertad" appears three times in the 1860 Leaves of Grass, but nineteen times in 1867 and eighteen times in $1881 .{ }^{42}$ In 1867, a verse on "Libertad, from the conqueress' field return'd," enters "Ontario," providing what Michael Moon reads as a destabilization of political (and gendered) powers. ${ }^{43}$ Whitman, for all his interest in non-Anglo-Saxon-derived words, was hardly likely to use a Spanish word in the immediate wake of the Mexican War and all the accompanying devaluation (including his own) of Spanish-derived culture. But by 1881, Libertad gains a primary importance in the text; in the Phantom's exhortation, the poet is told to "strike up the marches of Libertad" (LGVar 190). Over time, Whitman apparently moved away from Anglo-Saxonist language experiments. In the twelfth ramble of Rambles amongWords (1864), thought to have been co-authored by Whitman and William Swinton, the speaker disclaims such projects as unworthy and ridiculous: "The theory of English scholars and literateurs, for hundreds of years, has been the theory of repression. They have discouraged and cramped the spontaneous expansions of the Language- discouraged inoculations from the French, from Latin, Greek, Italian. What pitiful cant, too, does one hear every day about Saxon! as though it were not the very theory of the English languagethe very genius and animus of it - to take its food from all sources! This ridiculous nonsense is to be utterly dismissed." 44 I take the "pitiful cant" to refer to those contemporary scholars who wished to purify the English language down to its Anglo-Saxon elements.

As foreign words gain importance, Whitman's language politics mirror the racial politics of his 1883 letter to Santa Fé, which acknowledged the importance of Spanish contributions to America. In this letter, published as "The Spanish Element in Our Nationality," he declares:

We Americans have yet to really learn our own antecedents, and sort them, to unify them. They will be found ampler than has been supposed, and in widely different sources. Thus far, impress'd by New England writers and schoolmasters, we tacitly abandon ourselves to the notion that our United States have been fashion'd from the British Islands only, and essentially form a second England only - which is a very great mistake. Many leading traits for our future national personality, and some of the best ones, will certainly prove to have originated from other than British stock. ... To that composite American identity of the future, Spanish character will supply some of the most needed parts. (PW 552-553)

Anglo-Saxon stock provides pluck, courage, and the words of friendship and strength; if foreign stock provides the words of specialization 
or subtlety, it seems a fair assumption that Whitman values the more specialized qualities of the Spanish (among others). His attitude compares interestingly with that of a writer in the National Era, in an article entitled "Races of Men":

We do not know, or care to know, the precise relative proportions of Celtic, Anglo-Saxon, Norman, Teutonic, Indian, and Ethiopian elements that enter into the composition of that complex being, an American: all we know is, that he is neither English, Irish, German, Turk, African, nor Indian, but an American . . We are not a mongrel People, not a confederation of many races ... we are one People, a homogeneous people, with one name, one language, one creed in politics, one political system. We are Americans; our language is American; our political creed is American; our government is American ... But if the question be asked, to what People we are most nearly related, by our institutions, our language, our literature, our religion, our social usages and industrial pursuits ... [we] must reply, the English. ${ }^{45}$

This writer's racial theories sound like Whitman's early linguistic theories; he deliberately foregrounds the English stock even while stressing the importance of diversity to the American identity. Apparently, very similar content could be very differently theorized. In yet another Era article, the writer stressed the Englishness far over the diversity, going so far as to link national interests: "So far as race is concerned, it is England in another latitude and longitude; the identity is not to be mistaken; the language, the literature, the habits, the modes of thinking, and the interests, are not severable." ${ }^{46}$ One assumes that writers being published in the foremost abolitionist magazine must be against slavery and proponents of some degree of racial equality. But this does not stop any of them from valuing the Anglo-Saxon heritage that links England and America; many of the contemporary articles glory in the expansion of the Anglo-Saxon race, and their heritage of freedom. England and America are even described as sharing the unfortunate similarity of committing two major violations against freedom: Indians and black slaves for America, and Ireland and British India for England. ${ }^{47}$

Whitman's dynamic Anglo-Saxonism can also be followed in the changes of his treatment of American commercial superiority. In both "Salut Au Monde!," first published in 1856,48 and "Passage to India," first published in 1871, Whitman sees the world connected by technology, particularly railroads and telegraph wires. This expansion ofWestern technology spreads the "news of the wars, deaths, losses, gains, passions, of my race. ... I see the constructiveness of my race, / I see the results of the perseverance and industry of my race" (LGVar 167, 172). ${ }^{49}$ The "I" refers to Walt Whitman, who is asked, "What do you see Walt Whitman?" Answering for himself, one could argue that Walt Whitman is referring to "[his] race" as America, as the universal race of man, or as the Anglo-Saxon race. But his language borrows from the popular rheto- 
ric of industry and Anglo-Saxonism. Referring to the commonly valued qualities of the Anglo-Saxons - constructiveness, wars, industry-could signal to the contemporary reader that the Whitman speaking in the poem was upholding Anglo-Saxon supremacy in familiar fashion over all the races that he sees and salutes. The speaker finds not only "equals and lovers" but those who "will come forward in due time to my side," like those "own'd persons dropping sweat-drops or blood-drops," the slaves of the world (LGVar 174). As he makes his salutation "in America's name," he salutes on behalf of the dominant Anglo-Saxon race of which he is a member.

But Whitman also later vehemently opposed the Anglo-Saxon expertise in commerce. In "Death of Longfellow" (1882), Whitman claimed, "He is certainly the sort of bard and counteractant most needed for our materialistic, self-assertive, money-worshipping, Anglo-Saxon races," juxtaposing Longfellow's "melody, courtesy, deference" and use of the mellow past to the present rule of the "financier, the politician and the day workman" ( $P W$ 285). Likewise, his turn against imperialism seen in Democratic Vistas (1871) works against the use of Anglo-Saxonist rhetoric. ${ }^{50}$

In condemning commerce, Whitman was opposing a definite if somewhat troubled source of unity for the two Anglo-Saxon countries. Some felt that the unity was emphasized to the detriment of American business. The AmericanWhig Review complained, "[T] here is no occasion to ... refuse to acknowledge our common origin as a nation with that Anglo-Saxon people, against whom we have contended in two wars for independence, but who still hold us in commercial subjection, in consequence of our false system of legislation; which, contrary to the spirit of our Anglo-Saxon ancestors, refuses to protect our own industry." 51 However, a National Era correspondent supposedly from London seemed to feel that America was protecting itself far too strongly, through high import duties and port charges, and thereby causing rifts. According to him, "The evil results are immense; for these wretched bickerings actually retard the principle of progress throughout the continent of Europe, and, to that extent, frustrate the sacred mission of the Anglo-Saxon race." ${ }^{52}$ Both writers consider the "common origin" of America and England to be undeniable, and both countries clearly have thriving business practices which conflict with each other but dominate the rest of the world. The "bickering" clearly had gone far enough to provoke Whitman into writing the two "Anglo-Saxon races" off as "money-worshipping." By this time, he had also written the letter to Santa Fé, citing the importance of the Spanish character. Whether Whitman's views had mellowed with time and the Civil War is difficult to prove, but certainly, his later works seem to indicate that such was the case.

These fine considerations of Anglo-Saxonism rest on the central 
question of racialization and racism; had the self-declared poet of slaves ultimately resisted Anglo-Saxon racial supremacy? In Whitman's corpus, it is resisted by his acclamation of the American race as diverse, the "race of races." In the "Song of the Answerer," an American walks the world taking on different racial identities, chameleon-like. "The English believe he comes of their English stock, / A Jew to the Jew he seems . . . . a Russ to the Russ . . . . usual and near . . . removed from none" (LGVar 140). His adaptability lasts throughout all the editions of Leaves of Grass. But even as a "race of races," many contemporaries maintained that Americans were still Anglo-Saxon at heart, assimilating other nationalities. The American Whig Review proudly asserted that the "ready adoption by the various masses [of peoples] of the Anglo-Saxon language" indicated that the influx of immigrants would not change the essentially Anglo-Saxon character of America. Instead, "it should be the duty of all true Americans to discourage the separate action and trans-atlantic attachments and associations of the foreigners who come to reside among us; and to impress upon them the truth, that as all meet here on equal ground, so all distinctions of race should here be lost sight of, and all denizens, from whatever land or clime, should be anxious to be known in this republic only by the common name of AMERICANS." ${ }^{33}$ The racial assimilation paralleled the theory of development of the language, which took its foreign "food" or "contributions" but still remained the English language, though Americans would use it better. WhateverWhitman actually meant when he referred to a "race of races" (LG 711) or "nation of clusters of equal nations" (LGVar 156) in 1855, it was not clearly a contradiction of these views.

In "By Blue Ontario's Shore," the narrator moves past the conception of race and nation as the most important units of measurement and says, "I swear I begin to see the meaning of these things, / It is not the earth, it is not America who is so great, / It is I who am great or to be great, it is you, or any one ... I swear nothing is good to me now that ignores individuals" (LGVar 206). The individual's capacity, rather than the talents of the race, become for Whitman the foundation of future thought. A flicker of the former racialized thinking appears when the speaker says, "I swear I will have each quality of my race in myself, / (Talk as you like, he only suits these States whose manners favor the audacity and sublime turbulence of the States)," which entertains no possibility of variety in "manners" (LGVar 206-207). The possibility of having an individual embody the qualities of the race produces a vision of the future which is not negotiated by the idea of race; one must trust to some of Whitman's other politics of equality to ensure that non-Anglo-Saxon individuals can embody the qualities of "the race," perhaps the mingled American race of races.

Though individualism may seem like an invigorating alternative 
to Anglo-Saxonism, even individualism is complicit with imperialism for Walter Grünzweig. He argues, "'An empire is an immense egotism,' Emerson complains accusingly, but would his protégé Walt Whitman have worried about this a great deal? It is, after all, precisely a version of egotism, both of the self and his nation, which Whitman celebrates and which shows that the American empire, far from the exceptionalist claim made for it by its early revisionist propagandists, is not so far from the British version after all. ${ }^{\circ 4}$ Behdad and Phillips, too, are troubled in very different ways by the connection between individuals and the collective, the seeming ability of the individualistic philosophy of self-improvement to empower expansionism (Behdad) or eugenics (Phillips). But the egotism of the nation cannot be conflated with the egotism of the self; indeed, the struggle of the individual's rights against the national government's power was a fundamental problem in early American politics. ${ }^{55}$ America, as Whitman says, makes its "compact with individuals." Whitman's individualism explicitly combats the control of race, nation, or any other grouping - though rather than triumphing in any concrete way, it circles back to the problem of defining the American individual.

Whitman's attempts at celebrating his America were fraught with the contemporary discourse about America's Anglo-Saxon descent, as well as his own early Anglo-Saxonism and racism. Even egalitarian speakers in the nineteenth century fell into the trap of racism, led by their own earnest belief in the Anglo-Saxon destiny. Christianity might "[exclude] all conventionalism, and [dethrone] the aristocracy of class and birth, of skin and color," ${ }^{56}$ but it rested with the demonstrably superior AngloSaxon race to make all men "happy and good." Anglo-Saxonism was so prevalent that even celebrations of America that did not refer explicitly to its Saxon roots could provoke the same reader reaction. Seemingly apolitical philology blended into discussions of hereditary racial traits, and from there, soon moved towards Anglo-Saxonist imperialism. While Whitman's celebration of the individual could push against the limits of Anglo-Saxonist discourse, that resistance is complicated by the individual's inheritance of racial traits. Still, Whitman's changing views on language and Anglo-Saxonist politics over time demonstrate the relationship of one thinker to the complicated discourse of his time. As "an uncanny survivor and a piteous casualty of the ravages of the Civil War," ${ }^{57}$ Whitman's complication of the justifications for imperialism was a prophetic voice in the wilderness of the increasingly Anglo-Saxonist and imperialist discourse of late nineteenth-century America.

Northwestern University

NOTES 
My thanks to Jay Grossman and the $W W Q R$ reviewers for their thoughtful commentary, and to Betsy Erkkila for many inspiring conversations.

1 Eric Lott, Love and Theft: Blackface Minstrelsy and the American Working Class (New York: Oxford University Press, 1993), 79.

2 Jay Grossman, Reconstituting the American Renaissance: Emerson, Whitman, and the Politics of Representation (Durham, NC: Duke University Press, 2003), 181.

3 Dana Phillips, "Nineteenth-Century Racial Thought and Whitman's 'Democratic Ethnology of the Future'," Nineteenth-Century Literature 49 (1994), 298.

4 “The Anglo-Saxon," Littell's Living Age (August 12, 1848), 301.

5 See C. Carroll Hollis, Language and Style in Leaves of Grass (Baton Rouge: Louisiana State University Press, 1983).

6 “Anglo-Saxon Literature," The American Biblical Repository (July 1841), 197.

7 Matthew Frye Jacobson, Whiteness of a Different Color (Cambridge: Harvard University Press, 2003).

8 “Anglo-Saxon Literature," 211.

9 "The Mission of the Anglo-Saxon Race, Part II," National Era (October 20, 1853), 165.

10 "How the World Regards It," National Era (July 29, 1847), 1. There are too many references to list here, but some interesting articles that treat the subject at length are the following: "The Anglo-Saxon Race," The United States Magazine (May 15, 1854); "Development of the Anglo-American Mind," The Yale Literary Magazine (May 1848); "Progress of the Anglo-Saxon Race," The Literary World (July 26, 1851); "Manifest Destiny," Appletons' Fournal of Literature, Science and Art (March 26, 1870).

11 See Allen Frantzen, Desire for Origins (New Brunswick, NJ: Rutgers University Press, 1990).

12 "The Mission of the Anglo-Saxon Race, Part I," National Era (September 15, 1853), 147.

13 Theodore Parker, “The Anglo-Saxon Race," Niles' National Register (September 13, 1848), 173.

14 Reginald Horsman, Race and Manifest Destiny (Cambridge: Harvard University Press, 1981), 176. Horsman's comments on Theodore Parker are on p. 180.

15 "How the World Regards It," 1.

16 “The Poets and Poetry of Europe," North American Review (July 1845), 208.

17 Horace Traubel, With Walt Whitman in Camden, ed. Sculley Bradley, vol. 4 (Philadelphia: University of Pennsylvania Press, 1953). See the entry of February 4, 1889 (83-88).

18 "Robert Burns as Poet and Person," in Floyd Stovall, ed., Prose Works 1892 (New York: New York University Press, 1964), 2:558-568.

19 Richard Maurice Bucke, Thomas B. Harned, and Horace L. Traubel, eds., The Complete Prose Works of Walt Whitman (New York: G. P. Putnam's Sons, 1902), 7:39-60.

20 There was at least one other work called the Pictorial History of England, namely 
the version by Samuel G. Goodrich printed in 1845/1854/1871; David Hume's History of England is also occasionally referred to by this name.

21 "Critical Notices," The American Review: A Whig Fournal of Politics, Literature, Art and Science (June 1846).

22 The notes that make up American Primer are dated by John Bernbrock to the mid1850 s, based on a sheet of them that includes drawings for the 1856 Leaves of Grass spine. See John E. Bernbrock, "Walt Whitman and 'Anglo-Saxonism,"” Ph.D. Dissertation, University of North Carolina (1961), 10.

23 The American System of Education, A Hand-Book of Anglo-Saxon Derivatives (New York: D. Appleton \& Co., 1854); The American System of Education, A Hand-Book of Anglo-Saxon Root Words (New York: D. Appleton \& Co., 1854).

24 Walt Whitman, “America's Mightiest Inheritance," New York Dissected, ed. Emory Holloway and Ralph Adimari (New York: Rufus Rockwell Wilson, 1936), 58.

25 Whitman's clipping of Taylor's "Eve of the Conquest," Edinburgh Review 89 (April 1849), 187. From the Trent Collection at Duke University Library. Quoted in Bernbrock, "Walt Whitman and "Anglo-Saxonism," 125. The article argues that Saxon is superior to Latin.

26 Walt Whitman, “An American Primer,” Atlantic Monthly (April 1904), 468. Henceforth cited as $A P$.

27 See Linda Peavy, "Wooded Flesh and Metal Bone," Walt Whitman Review 20 (1974), 152-154.

28 See Betsy Erkkila, Whitman among the French (Princeton: Princeton University Press, 1980); Erik Ingvar Thurin, Whitman between Impressionism and Expressionism (Lewisburg, PA: Bucknell University Press, 1995); and James Nolan, Poet-Chief: The Native American Poetics of Walt Whitman and Pablo Neruda (Albuquerque: University of New Mexico Press, 1994).

29 Kerry C. Larson, Whitman's Drama of Consensus (Chicago: University of Chicago Press, 1988), 85.

30 James Perrin Warren views Whitman's compound words as expressions of temporality. See James Perrin Warren, Walt Whitman's Language Experiment (University Park: Pennsylvania State University Press, 1990).

31 From the "Preface 1855" in HaroldW. Blodgett and Sculley Bradley, eds., Leaves of Grass, Comprehensive Reader's Edition (New York: New York University Press, 1965), 727-728.

32 F. O. Matthiessen, American Renaissance: Art and Expression in the Age of Emerson and Whitman (London: Oxford University Press, 1941).

33 From "Sources of Character," in Floyd Stovall, ed., Prose Works 1892, 1:23.

34 Complete Prose Works of Walt Whitman, 23-24.

35 From the Feinberg Collection, Library of Congress, an unpublished essay entitled "Agitations, Dangers, in America," written circa 1855-1856, based on the paper type. Quoted in Bernbrock, "Walt Whitman and 'Anglo-Saxonism," 116.

36 From Whitman's Brooklyn Daily Eagle editorials in 1846. Quoted in Horsman, Race and Manifest Destiny, 235. 
37 "The Anglo-Saxons and the Americans: European Races in the United States," The American Whig Review (September 1851), 192.

38 See Amy Kaplan, "Romancing the Empire: The Embodiment of American Masculinity in the Popular Historical Novel of the 1890s," American Literary History 2 (1990), 659-690.

39 See Lora Romero, Home Fronts: Domesticity and Its Critics in the Antebellum United States (Durham, NC: Duke University Press, 1997).

40 Sculley Bradley, Harold W. Blodgett, Arthur Golden, and William White, eds., Leaves of Grass: A Textual Variorum of the Printed Poems (New York: New York University Press, 1980), 1:157.

41 Betsy Erkkila, Whitman the Political Poet (New York: Oxford University Press, 1989), 128.

42 According to the automated counts provided by the wonderfully helpful Walt Whitman Archive (www.whitmanarchive.com).

43 Michael Moon, Disseminating Whitman: Revision and Corporeality in Leaves of Grass (Cambridge, MA: Harvard University Press, 1991), 205.

44 See James Perrin Warren, "Whitman as Ghostwriter: The Case of Rambles among Words," Walt Whitman Quarterly Review 2 (Fall 1984), 22-30. The quotation is from Whitman, Notebooks and Unpublished Prose Manuscripts, ed. Edward F. Grier (New York: New York University Press, 1984), 5:1661.

45 “Races of Men,” National Era (November 27, 1851), 190.

46 "The Mission of the Anglo-Saxon Race, Part I," 147.

47 “Races of Men," 190.

48 "Salut Au Monde!" also includes the only direct mention of Anglo-Saxon literature/culture that I found in my survey of Whitman's corpus: "I see the burial-cairns of Scandinavian warriors, / I see them raised high with stones by the marge of restless oceans, that the dead men's spirits when they wearied of their quiet graves might rise up through the mounds and gaze on the tossing billows, and be refresh'd by storms, immensity, liberty, action" ( $L G$ 143). This sounds like Beowulf's cairn.

49 Walter Grünzweig, "The New Empire Grander Than Any Before: 19th-Century American Versions of a Democratic Imperialism," Empire: American Studies, ed. John G. Blair and Reinhold Wagnleitner, SPELL (Tübingen: Gunter Narr, 1997).

50 See Grünzweig, “New Empire,” 248.

51 "Progress of the Anglo-Saxon Race," 192-193.

52 "The Mission of the Anglo-Saxon Race, Part II," 165.

53 "The Anglo-Saxons and the Americans," 193.

54 Grünzweig, “New Empire,” 247.

55 Gordon S. Wood, “The Origins of Rights in the Early Republic," Language of Rights During the Age of the American Revolution (Conference, Northwestern University: May 21-22, 2004).

56 "The Mission of the Anglo-Saxon Race, Part I," 147. 
57 Moon, Disseminating Whitman, 221. 